\title{
Expansion range of the brick Seabass, Acanthistius pictus (Tschudi, 1846) (Serranidae: Osteichthyes), in Chilean waters
}

\section{Ampliación del rango de distribución de Acanthistius pictus (Tschudi, 1846) (Serranidae: Osteichthyes) en aguas chilenas}

\author{
Lidia E. Mansur ${ }^{1 *}$, Natalio Godoy ${ }^{1}$, Stefan Gelcich ${ }^{1}$, Cristian de la Barra ${ }^{2}$ \& Ramón Navarro ${ }^{3}$ \\ ${ }^{1}$ Departamento de Ecología, Center of Applied Ecology and Sustainability (CAPES), Pontificia Universidad Católica de Chile, \\ Santiago, Chile \\ Servicio Nacional de Pesca, oficina Pichilemu, VI Región del Libertador General Bernardo O’Higgins, Chile \\ ${ }^{3}$ Punta de Lobos s/n, Pichilemu, VI Región del Libertador General Bernardo O’Higgins, Chile \\ *E-mail: Imansur@bio.puc.cl
}

Acanthistius (Anthiinae) is distributed in the Indo West Pacific, Southeast Pacific and South Atlantic Ocean. The genus is constituted by 13 species, of which only Acanthistius pictus (Tschudi 1846) is recorded in Chile. A. pictus is an endemic serranid of the Eastern Pacific coast distributed from southern Perú $\left(16^{\circ} \mathrm{S}\right)$ to north of Chile $\left(26^{\circ} \mathrm{S}\right)$ (Pequeño et al. 2011). A. pictus is a rocky reef fish of shallow waters $(5-30 \mathrm{~m})$, that lives associated to caves and Lessonia trabeculata kelp forests (Cisternas \& Sielfeld 2008). It is a carnivorous species that feeds mainly on crustaceans (Medina et al. 2004). It is also an economically important species which supports small-scale artisanal fishing activities in the north of Chile (Godoy 2013).

The first record of $A$. pictus for Chile was conducted by Tschudi (1845), who determines that its distribution extends between $20^{\circ} \mathrm{S}$ and $26^{\circ} \mathrm{S}$. The 17 specimens that are preserved in London (MNHN) and Hamburg (ZMH) museums were collected exclusively in northern Chile (Fish base 2015), consistent with the first record. In this note, we report the southern expansion range of $\mathrm{A}$. pictus from $26^{\circ} \mathrm{S}$ to $34^{\circ} \mathrm{S}$, in Chilean waters.

In March of 2012, a recreational spearfisher caught one specimen of $A$. pictus at $5 \mathrm{~m}$ depth in the coastal area of Pichilemu $\left(34^{\circ} \mathrm{S} 72^{\circ} \mathrm{W}\right)$. The specimen was frozen whole and transported to laboratory of Pontificia Universidad Católica de Chile. The diagnosis features used for specimen identification was according to Pequeño et al. (2011). The main features considered were: Head: Premaxilla, dentary, vomer and palatine with a thin band of villiformes teeth (always less than 3 rows of teeth); not abruptly expandable jaw; more than 18 pseudobranchs; less than 90 sawing in preopercle; one antrorsa thorn in the ventral edge of preopercle. Fins: caudal fin truncated or forked; less than 21 pectoral rays; third, fourth and fifth pelvic radios unfused; last dorsal radius unstretched; caudal fin with unfused radios; more than 11 dorsal spines. Morfometrics: preopercular distance greater than $5 \%$ of standard length, head length; more than $28 \%$ of the standard longitude; orbital diameter more than $10 \%$ head length; pelvic fin length of less than $35 \%$ of standard length; length of anal fin less than $20 \%$ of standard length. Scales: more than 90 scales in rows on the sideline; interorbital distance more than 6 scales; suborbital distance with more than five scales. Total length (LT) and total weight (TW) were recorded. The specimen was preserved in alcohol and deposited in the "Colección de Flora y Fauna, Profesor Patricio Sánchez Reyes, Pontificia Universidad Católica de Chile (SSUC-Pi 0087)". The determination analysis showed that the sample examined corresponds to an adult specimen of A. pictus with a total length of $38.2 \mathrm{~cm}$ and total weight of $1061 \mathrm{~g}$. This result extends the distribution range of $A$. pictus from $26^{\circ} \mathrm{S}$ to $34^{\circ} \mathrm{S}$ (Fig. 2).

Field and anecdotal observations suggest that the southern distribution of A. pictus would extend to Valparaíso $\left(33^{\circ} \mathrm{S}\right)$ (Mann 1954; Chirichigno 1974; Moreno \& Castilla 1982; Ojeda et al. 2000), but these studies do not detail the sites of capture and collection registered. We consider that Pichilemu $\left(34^{\circ} \mathrm{S}\right)$ is the southernmost documented record for $A$. pictus.

A. pictus is a component of rocky reef fish assemblage which showed links to more septentrional regions (Ojeda et al. 2000; Rojas \& Pequeño 2000). This finding adds to recent records of other three rocky reef fish species Cheilodactylus variegatus, Chromis crusma and Graus nigra which have been reported to extend their distributions to Valdivia $\left(39^{\circ} \mathrm{S}\right)$ (Pequeño 2001, Vargas and Pequeño 


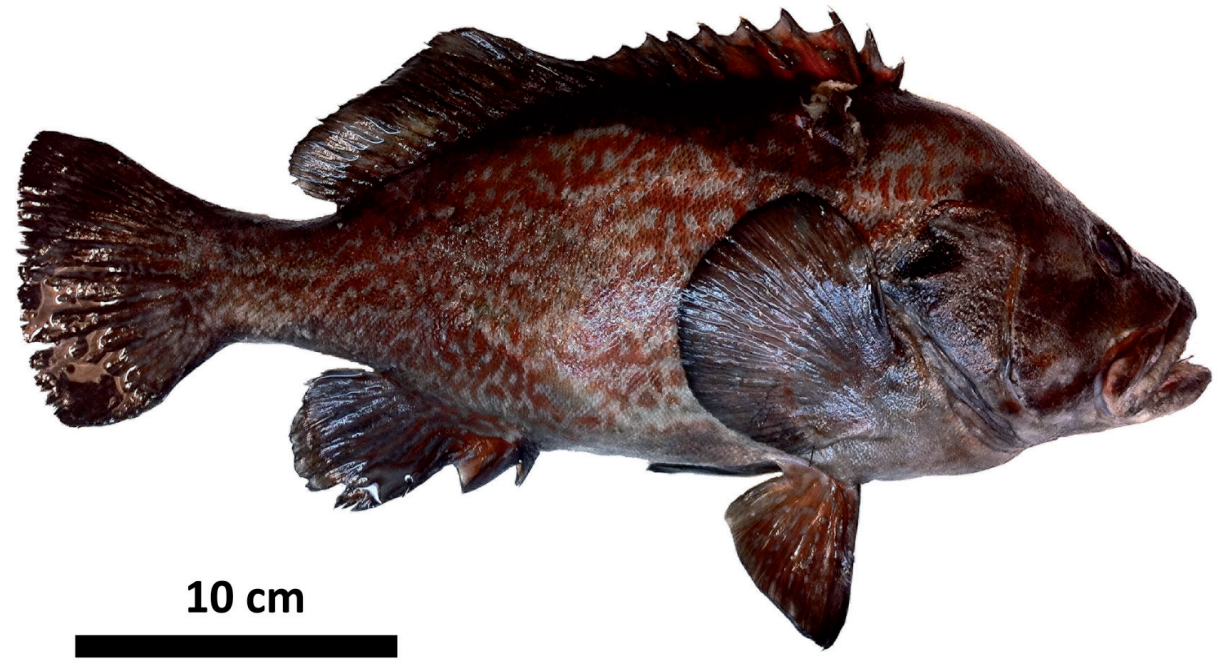

FIGURE 1: Acanthistius pictus SSUC-Pi 0087

Figura 1: Acanthistius pictus SSUC-Pi 0087

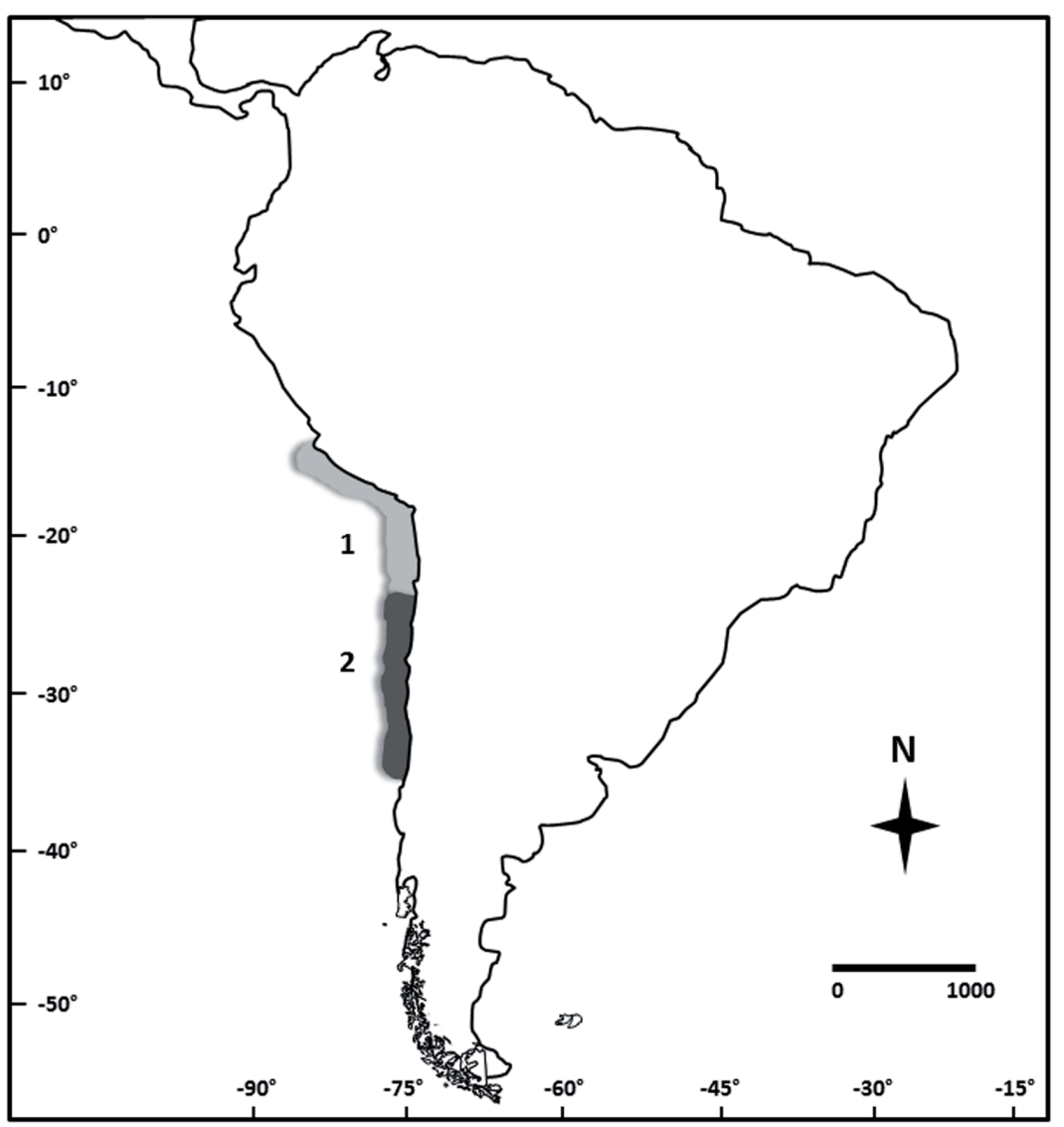

FIGURE 2: Acanthistius pictus (1) distributional range by Tschudi (1845) and 2: extended range by present work.

Figura 2: Acanthistius pictus (1) rango de distribución por Tschudi (1845) y 2: rango extendido en el presente trabajo. 
2001). Different hypotheses have been proposed to explain this trend: a) the limited exploration of the coastal Chile, referring to the geographical distribution of coastal rocky reef fish and; b) the septentrional invading fish species (Mann 1954) due to climate change or during warm El Niño Southern Oscillation events (Vargas \& Pequeño, 2004). Unfortunately, subtidal ecological information in Chile is scarce, which for the moment makes it impossible to assess these different hypotheses about the determinants of distribution change, but it is possible to infer an interesting pattern on the southern extension of the distribution of rocky reef fish species with northern affinities. Such evidence is relevant when ichthyogeographical considerations are proposed.

We thank Veronica Ortiz for his help in this note. N. Godoy thanks to FONDECYT 3150138. We thank financiamiento Basal 0002 and the Walton Family foundation.

\section{BIBLIOGRAPHY}

Chirichigno, N. 1974. Clave para identificar los peces marinos del Perú. Informes del Instituto del Mar Perú-Callao 11:1-387.

Cisternas, F. \& Sielfeld, W. 2008. Habitat overlap of Paralabrax humeralis (Cuvier \& Valenciennes, 1828), Hemilutjanus macrophthalmos (Tschudi, 1845), and Acanthistiuspictus (Tschudi, 1845) (Pisces; Serranidae) in the rocky subtidal south of Iquique, Chile. Latin American Journal of Aquatic Research 36:153-158.

EsCHMEYer \& FonG, 2015. Fishbase. URL: http://www.fishbase. org

Godoy, N. 2013. Pesquería artesanal por buceo de peces de roca en el centro norte de Chile : diagnóstico del sistema socialecológico y los desafíos para su sustentabilidad. Tesis para optar al grado de doctor en Ciencias Biológicas, mención Ecología. Pontificia Universidad católica de Chile, Santiago, Chile.

ManN, G. 1954. Vida de los peces en aguas chilenas. Instituto de Investigaciones Veterinarias y Universidad de Chile, Santiago, $342 \mathrm{pp}$.

Medina, M., Araya, M. \& Vega, C. 2004. Alimentación y relaciones tróficas de peces costeros de la zona norte de chile. Investigaciones Marinas 32:33-47.

Moreno, C. A. \& Castilla, J.C. 1982. Guía para el reconocimiento y observación de Peces de Chile. 115pp.

OjedA, F. P., LABra, F. A. \& MuÑoz, M. M. 2000. Biogeographic patterns of Chilean littoral fishes. Revista Chilena de Historia Natural 73:625-641.

PequeÑo, G. 2001. El "bilagai" Cheilodactylus variegatus Valenciennes, 1833, en la costa de Valdivia (Osteichthyes: Cheilodactylidae). Estudios de Oceanología 20, 23-28.

Pequeño, G., Rojas, J. R. \& SÁez, S. 2011. Clave ilustrada de los peces chilenos de la familia Serranidae (Teleostei: Perciformes). Revista de Biología Tropical 59:247-253.

Rojas, J. R. \& Pequeño, G. 2000. Revisión taxonómica de especies de las subfamilies Epinephelinae y Serraninae (Pisces: Serranidae) de Chile. Revista de Biología Tropical 49:157171.

Tschudi, J. J. von. 1845. Ichthyologie. Pp. ii-xxx + 1-35, Pls. 1-6. In: Untersuchungen über die Fauna Peruana. Scheitlin \& Zollikofer:1-693.

Vargas, L. \& Pequeño, G. 2001. Hallazgo del bilagai (Cheilodactylus variegatus Valenciennes, 1833), en la bahía Metri, Chile (Osteichthyes: Cheilodactylidae). Investigaciones Marinas. 29:35-37.

Vargas, L. \&. Pequeño, G. 2004. El estatus taxonómico de Graus fernandezianus Philippi, 1887; nuevo registro geográfico y comentarios sobre Graus nigra Philippi, 1887 (Osteichthyes: Perciformes). Gayana 68:68-74.

Recibido: 17.03 .16

Aceptado: 31.08 .16 